\title{
Impact of Land use and Cover Change on Soil Organic Carbon and Total Nitrogen Storage in the Helmand River Basin
}

\author{
Zara Rahmani* \\ Lecturer, Department of Geography Education Faculty, Jawzjan University, Sheberghan, Afghanistan \\ *Corresponding Author: Zara Rahmani, Lecturer, Department of Geography Education Faculty, \\ Jawzjan University, Sheberghan, Afghanistan
}

\begin{abstract}
Land use/land cover changes, whether they are natural or anthropogenic, have both positive and negative impacts on hydrological processes, and water resources. This manuscript examines quantity and distribution of SOC and total $N$ under various developmental stages of different land uses in Helmand river basin, Afghanistan. Soil organic carbon (SOC) and total nitrogen $(N)$ data were collected from Helmand river basin at a sampling depth of just 0-10, 0-20 and 20-40 cm. Soil organic carbon was lowest when the depth of the soil was increased. Highest total nitrogen of $0.87 \mathrm{~g} \mathrm{Kg-1} \mathrm{was} \mathrm{recorded} \mathrm{in} \mathrm{natural} \mathrm{grass} \mathrm{land} \mathrm{at} \mathrm{30-60} \mathrm{cm}$ soil depth. DSOC of shrub land, forest, natural grassland, farmland and wetland were 6.58, 4.37, 7.01, 3.6 and $4.55 \mathrm{~g} \mathrm{~cm}-2$. In the case of shrub land, highest DTN of $0.47 \mathrm{~g} \mathrm{~cm}-2$ was found. The results demonstrate that the Land use/land cover changes caused significant losses in both SOC and TN storage in the river basin.
\end{abstract}

Keywords: land use, organic carbon, total nitrogen, land cover change

\section{INTRODUCTION}

River basins of arid and semi-arid regions in developing countries, where water is a scarce resource, are facing drastic land use/land cover changes as a result of rapidly increasing human population and socio-economic developments. The consequences of earth's land surface transformation on biophysical and ecological systems are urban heat islands, alteration in stream flow pattern, global atmospheric circulation, and even extinction of living species (Yu et al. 2011).

When considering global climate change, land use has become a key factor that is directly related to food security (Tao et al., 2009), water and soil quality (Mueller Warrant et al., 2012), and other life support issues. Soil organic carbon is an important element of the global carbon stock and contains approximately two times more carbon than the atmosphere or vegetation. Soil organic carbon and total nitrogen are the key indicators for estimating soil quality and act as important carbon and nitrogen reservoirs, and understanding the distribution of SOC and total $\mathrm{N}$ stocks are essential in achieving improvements in soil quality.

Land use/land cover changes, whether they are natural or anthropogenic, have both positive and negative impacts on hydrological processes, and water resources (Gajbhiye et al. 2015) and soil nutrients (Kumar et al. 2013).A number of studies have reported the impact Land use/land cover changes on hydrological processes at different spatial and temporal scales (Baker and Miller 2013; Fan and Shibata 2015; Zhou et al. 2013). He and Hogue (2012) noted that urbanization was often the most influential factor that affected flow regimes in a basin. Further, the article reported that an increase in urban development had caused an increase in the total annual runoff and wet season flows in Upper Santa Clara Basin in the United States of America (USA). Jing and Ross (2015), on the other hand, assessed the possible relationship between LULC and stream flow due to mining activities in Peace River in Southwest Florida and found out that there was a decreasing pattern in stream flow at most gauging stations which were impacted by upstream mining activities. Furthermore, impacts of LULC changes on the water resources have been analyzed in many other studies at different spatial and temporal scales (Legesse et al. 1995; Wang et al. 2008; Ghaffari et al. 2010; Mango et al. 2011; Barthel et al. 2012; Wijesekara et al. 2012; Yan et al. 2013). This manuscript examines quantity and distribution of SOC and total $\mathrm{N}$ under various developmental stages of different land uses in Helmand river basin, Afghanistan. 


\section{Materials AND Methods}

The HRB is a closed river basin, draining into a series of terminal lakes (locally called hamouns) in the Sistan Depression near the Afghan - Iranian border. It has a total area of approximately 400,000 $\mathrm{km}^{2}$ spread across southern Afghanistan (81.4\% of the basin), Iran (15\%) and Pakistan (3.6\%). The elevations in the basin range from over 4400 metres above sea level (masl) in the edges of the Hindu Kush mountains in the north-east, where most of the rivers originate, to 490 masl in the Sistan depression in the south-west. Mean annual precipitation varies from about $50 \mathrm{~mm}$ in the south-west to almost $300 \mathrm{~mm}$ in the north-east part of the basin. Precipitation occurs mostly in the winter months, and falls mostly as snow in the upper basin. For the Upper Helmand Sub Basin (upstream of Kajaki Reservoir) it is estimated, based on a rainfall-runoff model, that $70 \%$ of precipitation falls as snow. Peak runoff occurs with snowmelt in April.

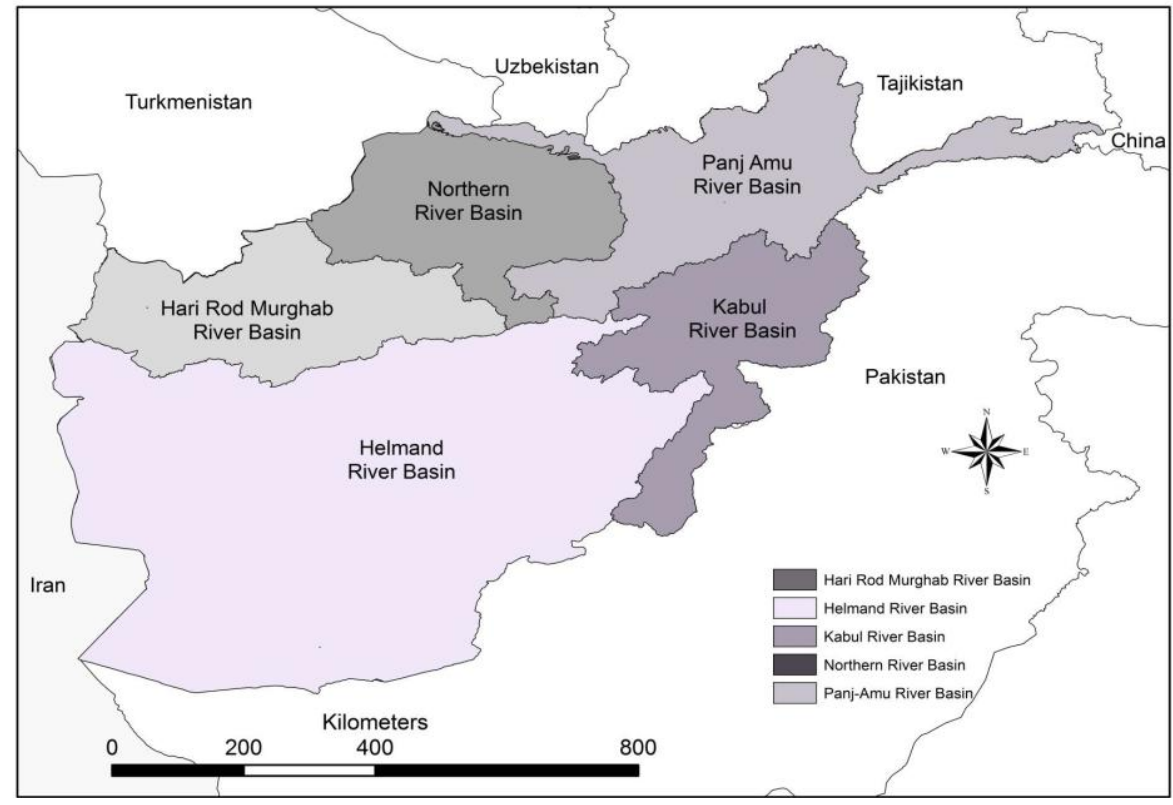

Fig1. The Helmand River basin

\subsection{Experimental Design and Sample Collection}

Soil organic carbon (SOC) and total nitrogen $(\mathrm{N})$ data were collected from Helmand river basin at a sampling depth of just $0-10,0-20$ and $20-40 \mathrm{~cm}$. A non-equidistant irregular grid $(0.8 \times 0.8 \mathrm{~km})$ method was used for sample collection. Six or seven replicated points were collected for each site. The dichromate oxidation method was used to measure SOC and the micro Kjeldahl method was used to determine total nitrogen (Nelson et al., 1975). The core ring method was used to determine bulk density.

The density of soil organic carbon total nitrogen can indicate the contributions of global changes that form soil quality and terrestrial ecosystem. Generally, the mass of soil organic carbon and total nitrogen contained in soil per square meter, that represent soil organic carbon density and soil total nitrogen density.

$$
D_{S O C}=\sum_{i=1}^{n}\left(1-C_{i}\right) \times B_{i} \times 0.58 \times \operatorname{SOM}_{i} \times H_{i} / 10
$$

DSOC - Soil organic carbon density

$\mathrm{Ci} \quad-$ The gravel content on layer i (particle size $>2 \mathrm{~mm}$, volume \%);

$\mathrm{Bi} \quad$ - Soil bulk density on layer i $(\mathrm{g} / \mathrm{cm} 3)$;

SOMi - The content of soil organic carbon on soil layer i $(\mathrm{g} / \mathrm{kg})$;

$\mathrm{Hi} \quad$ - The thickness of the soil $(\mathrm{cm})$;

$\mathrm{n} \quad$ - The numbers of total soil layer $(\mathrm{cm})$;

0.58 - The conversion coefficient of Bemmenlen (SOC); 


$$
D_{T N}=\sum_{i=1}^{n}\left(1-C_{i}\right) \times B_{i} \times T N_{i} \times H_{i} / 10
$$

DTN -Soil total nitrogen density;

$\mathrm{Ci} \quad$ - The gravel content on layer i (particle size $>2 \mathrm{~mm}$, volume \%);

$\mathrm{Bi} \quad$ - Soil bulk density on layer i $(\mathrm{g} / \mathrm{cm} 3)$;

$\mathrm{TNi} \quad$ - The content of total nitrogen on soil layer i $(\mathrm{g} / \mathrm{kg})$;

$\mathrm{Hi} \quad$ - The thickness of the soil $(\mathrm{cm})$;

$\mathrm{n} \quad$ - The numbers of total soil layer $(\mathrm{cm})$;

$$
\begin{aligned}
S_{S O C} & =\sum_{i=1}^{n} S_{i} \times D_{S O C i} \\
S_{T N} & =\sum_{i=1}^{n} S_{i} \times D_{T N i}
\end{aligned}
$$

SSOC, STN - Soil organic carbon storage, soil total nitrogen storage;

$\mathrm{Si} \quad-$ The area of land uses;

DSOC, DTN - Soil organic carbon density, soil total nitrogen density;

\section{RESULTS AND DISCUSSION}

Soil organic carbon was determined from various land use type studied. Soil depth of 0-10, 10-30 and $30-60 \mathrm{~cm}$ was considered while collecting the samples from the total 5 land use types studied. At soil depth of 0-10 cm, organic carbon was in the range of 6.34-14.9 $\mathrm{g} \mathrm{Kg}^{-1}$. Grass land has recorded highest organic carbon followed by shrub land. In the case of soil depth of $10-30 \mathrm{~cm}$, soil organic carbon was between 5.41 and $12.4 \mathrm{~g} \mathrm{Kg}^{-1}$ with maximum content recorded in grass land. However, soil organic carbon was lowest when the depth of the soil was increased. In other words, lowest content of $3.19 \mathrm{~g} \mathrm{Kg}^{-1}$ was found in forest land and the highest organic carbon content of $7.54 \mathrm{~g} \mathrm{Kg}^{-1}$ was found in natural grass land.

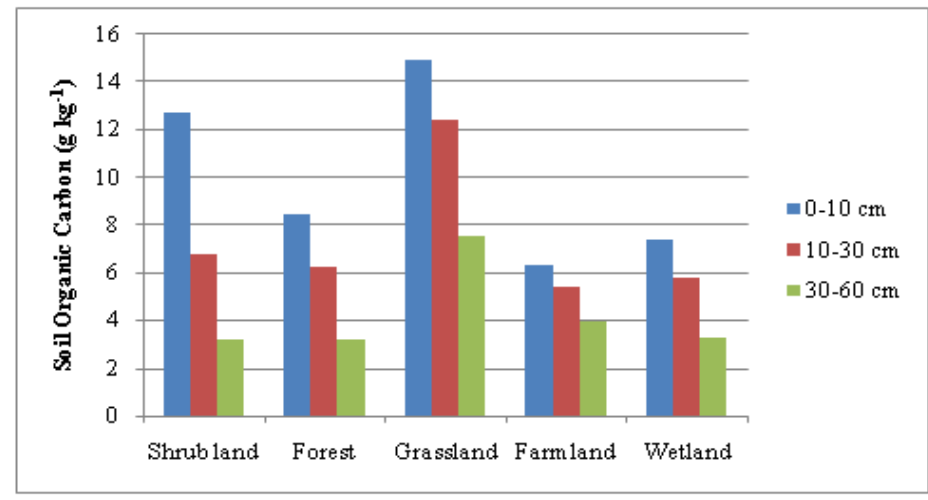

Fig2. Soil Organic carbon $\left(g \mathrm{Kg}^{-1}\right)$

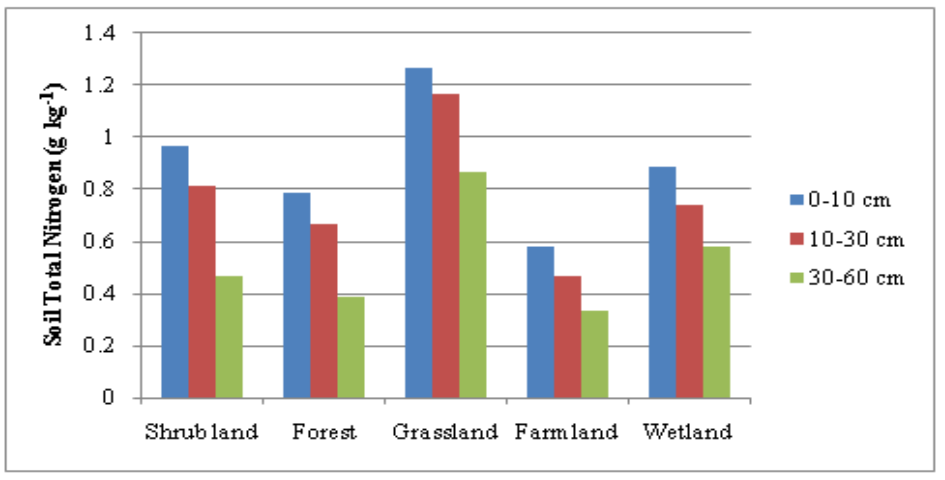

Fig3. Soil Total Nitrogen $\left(g \mathrm{Kg}^{-1}\right)$ 
Total soil nitrogen was estimated by micro Kjeldahl method and the findings were varying with depth of soil as well as type of land use studied. Soil depth of 0-10 $\mathrm{cm}$ and 10-30 $\mathrm{cm}$ contained total nitrogen in the range of $0.58-1.27 \mathrm{~g} \mathrm{Kg}^{-1}$ and $0.47-1.17 \mathrm{~g} \mathrm{Kg}^{-1}$ respectively. Similar to organic carbon, total nitrogen of land use type studied was reduced with increasing soil depth. Highest total nitrogen of $0.87 \mathrm{~g} \mathrm{Kg}^{-1}$ was recorded in natural grass land at $30-60 \mathrm{~cm}$ soil depth.

Density of soil organic carbon $\left(\mathrm{D}_{\mathrm{SOC}}\right)$ and total nitrogen $\left(\mathrm{D}_{\mathrm{TN}}\right)$ were determined for the land use types and shown in figures 4 and 5. DSOC of shrub land, forest, natural grassland, farmland and wetland were $6.58,4.37,7.01,3.6$ and $4.55 \mathrm{~g} \mathrm{~cm}^{-2}$. In the case of shrub land, highest DTN of $0.47 \mathrm{~g} \mathrm{~cm}^{-2}$ was found followed by natural grass land $\left(0.44 \mathrm{~g} \mathrm{~cm}^{-2}\right)$

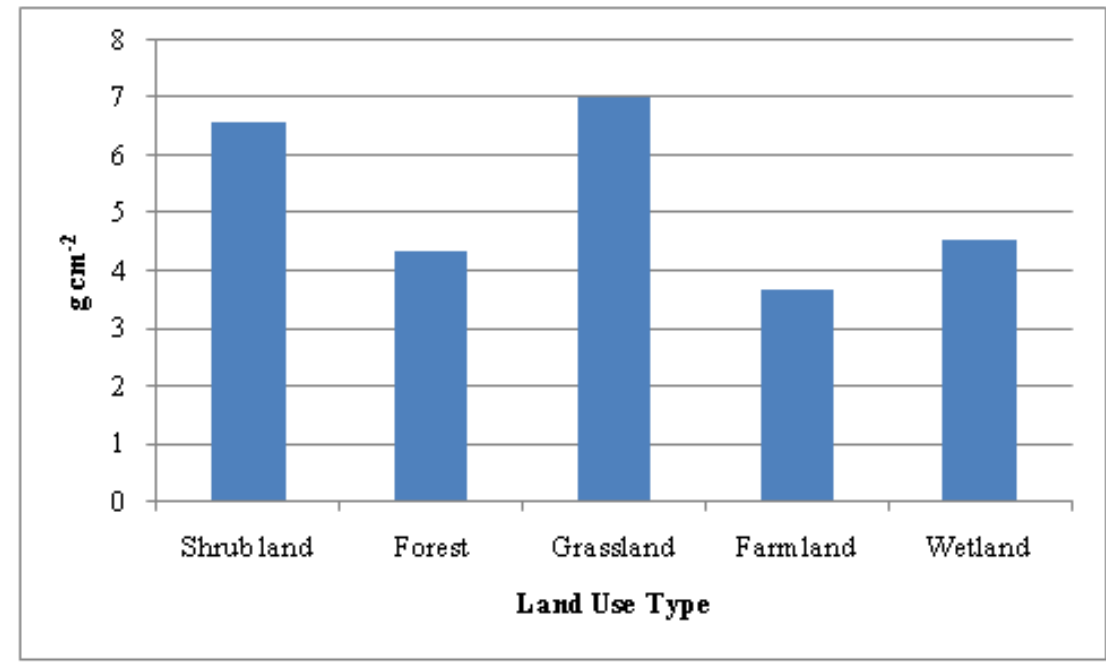

Fig4. Soil Organic Carbon Density

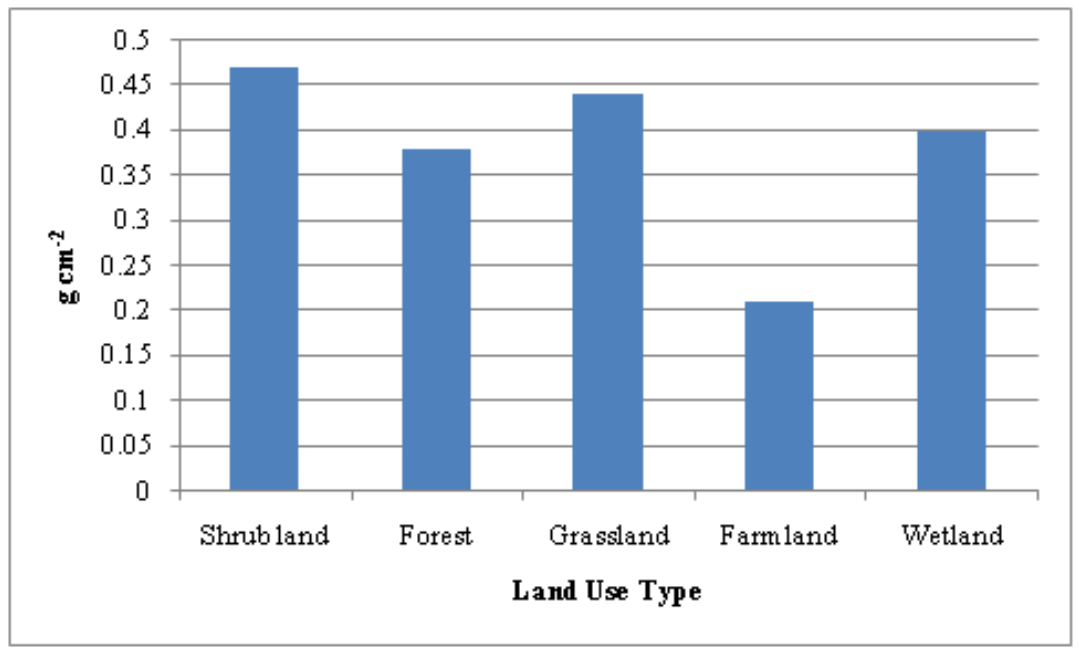

Fig5. Soil Total Nitrogen Density

\subsection{Discussion}

Verburg et al. (1999) stated that the population growth and intensive agriculture leads to land use changes. The grain requirement by human mass and building of farmland accelerate the deforestation. The conversion of grassland into cultivated land and further deforestation disturb the water elaboration. These factors continuously results the degradation in ecological services. The construction of reservoirs in an uneven topographical region could cause the likelihood of sudden flooding due to failure of such construction. The physical habitat characteristics, water quality, biotic interactions and energy inputs in a lotic system are generally affected by alterations in the stream flow regime. These alterations have seriously become a threat to the riverine biodiversity (Rolls et al. 2012). Webb et al. (2003) stated that the reduction in species richness due to loss of native species and changes in reproductive behaviour of the sensitive species are also influenced by the alteration in stream flow. Poff and Zimmerman (2010) reviewed that most of the scientific studies influenced a 
variety of ecological responses by aquatic biota to streamflow alteration including changes in reproductive behavior, community shits based on trophic strategies, reduced species richness and in particular the loss of native and sensitive species. In addition with increasing magnitudes of flow alteration, the risk of ecological change is observed to increase.

\section{CONClusion}

The current study conducted a meta-analysis to investigate the response of soil organic carbon (SOC) and total nitrogen (TN) storage due to the land use and cover change in the Helmand River basin. The results demonstrate that the Land use/land cover changes caused significant losses in both SOC and TN storage in the river basin. However, the losses depend on specific land use pattern, the depth of the soil layer and the calculation method. Therefore, the effects of the specific land use pattern, the depth of the soil layer and the calculation method should be fully considered in future research. Further study is also needed to look into the fundamental processes and associated mechanisms.

\section{REFERENCES}

[1] Baker TJ, Miller SN (2013) Using the soil and water assessment tool (SWAT) to assess land use impact on water resources in an East African watershed. J Hydrol 486:100-111.

[2] Barthel R, Reichenau TG, Krimly T (2012) Integrated modeling of global change impacts on agriculture and groundwater resources. Water Resour Manag 26(7):1929-1951.

[3] Fan M, Shibata H (2015) Simulation of watershed hydrology and stream water quality under land use and climate change scenarios in Teshio River watershed, northern Japan. Ecol Indic 50:79-89.

[4] Gajbhiye S, Singh SK, Sharma SK (2015) Assessing the effects of different land use on water qualify using multi-temporal Landsatdata. In: Siddiqui AR SP (Ed) Resour Manag Dev Strateg A Geogr Perspect. Pravalika Publications, Allahabad, pp 337-348

[5] Ghaffari G, Keesstra S, Ghodousi J, Ahmadi H (2010) SWAT-simulated hydrological impact of land-use change in the Zanjanrood Basin, Northwest Iran. Hydrol Process 24(7):892-903

[6] He M, Hogue TS (2012) Integrating hydrologic modeling and land use projections for evaluation of hydrologic response and regional water supply impacts in semi-arid environments. Environ Earth Sci 65(6):1671-1685.

[7] Jing Z, Ross M (2015) Hydrologic modeling impacts of post-mining land use changes on streamflow of Peace River, Florida. Chin Geogr Sci 25(6):728-738.

[8] Kumar SK, Aier B, Khanduri VP, Gautam P, Singh D, Singh SK (2013) Assessment of soil nutrients (N, $\mathrm{P}, \mathrm{K}$ ) status along with tree diversity In different land use systems at Mokokchung. Nagaland India Sci Technol J 1:42-48.

[9] Legesse D, Vallet-couomb C, Gasse F (1995) Hydrological response of a catchment to climate and land use changes in Tropical Africa: case study South Central Ethiopia. J Hydrol 275(1-2):67-85.

[10] Mango LM, Melesse AM, Mcclain ME, Gann D, Setegn SG (2011) Land use and climate change impacts on the hydrology of the upper Mara River Basin, Kenya: results of a modeling study to support better resource management. Hydrol Earth Syst Sci 15:2245-2258.

[11] Mueller Warrant GW, Griffith SM, Whittaker GW, Banowetz GM, Pfender WF, Garcia TS, Giannico G. (2012). Impact of land use patterns and agricultural practices on water quality in the Calapooia river basin of western Oregon. J. Soil Water Conserv. 67 (3): 183-201.

[12] NelsonW, Sommer LE. (1975) Total carbon, organic carbon and organic matter. In Methods of Soil Analysis. Part 2; Sparks, D.L., Page, A.L., Helmke, R.A., Loeppert, R.H., Sottanpor, P.N., Tabatabai, M.A., Johnson, C.T., Sumner, M.E., Eds.; American Society of Agronomy and Soil Science Society of America: Madison, WI, USA.

[13] Poff NL, Zimmerman JKH (2010) Ecological responses to altered flow regimes: a literature review to inform the science and management of environmental flows. Freshwater Biol 55(1): 194-205.

[14] Rolls RJ, Catherine Leigh C, Sheldon F (2012) Mechanistic effects of low-flow hydrology on riverine ecosystems: ecological principles and consequences of alteration. Freshwater Sci 31(4):1163-1186

[15] Tao F, Yokozawa M, Liu J, Zhang Z. (2009) Climate change, land use change, and China's food security in the twenty-first century: an integrated perspective. Clim. Chang. 93: 433-445.

[16] Verburg PH, Veldkamp A, Bouma J (1999) Land-use change under conditions of high population pressure: the case of Java. Glob Environ Change 9(4): 303-312.

[17] Wang S, Kang S, Zhang L, Li F (2008) Modelling hydrological response to different land-use and climate change scenarios in the Zamu River basin of northwest China. Hydrol Process 22(14): 2502-2510. 
[18] Webb BW, Clack PD, Walling DE (2003) Water-air temperature relationships in a Devon river system and the role of flow. Hydrol Process 17: 3069-3084

[19] Wijesekara GN, Gupta A, Valeo C, Hasbani J, Qiao Y, Delaney P, Marceau DJ (2012) Assessing the impact of future land-use changes on hydrological processes in the Elbow river watershed in southern Alberta, Canada. J Hydrol 412-413:220-232.

[20] Yan B, Fang NF, Zhang PC, Shi ZH (2013) Impacts of land use change on watershed streamflow and sediment yield: An assessment using hydrologic modelling and partial least squares regression. J Hydrol 484:26-37.

[21] Yu W, Zang S, Wu C, Liu W, Na X (2011) Analyzing and modelling land use land cover change (LUCC) in the Daqing. Appl Geogr 31:600-608.

[22] Zhou F, Xu Y, Chen Y, Xu C, Gao Y, Du J (2013) Hydrological response to urbanization at different spatio-temporal scales simulated by coupling of CLUE-S and the SWAT model in the Yangtze River Delta region. J Hydrol 485:113-125.

Citation: Zara Rahmani. "Impact of Land use and Cover Change on Soil Organic Carbon and Total Nitrogen Storage in the Helmand River Basin" International Journal of Research in Geography. vol 6, no. 1, 2020, pp. 10-15 doi: http://dx.doi. org/10.20431/2454-8685.0601002.

Copyright: (C) 2020 Authors. This is an open-access article distributed under the terms of the Creative Commons Attribution License, which permits unrestricted use, distribution, and reproduction in any medium, provided the original author and source are credited. 